\title{
ALWAYS CONNECTED: A FIRST INSIGHT INTO THE INFLUENCE OF SMARTPHONE ADOPTION ON THE ACTIVITY-TRAVEL BEHAVIOUR OF MOBILE PROFESSIONALS IN INDONESIA
}

\author{
Gloriani Novita Christin \\ School of Architecture, Planning and Policy Development, \\ Institut Teknologi Bandung, Indonesia, glorinovi@yahoo.com \\ Ofyar Zainuddin Tamin \\ Department of Civil and Environmental Engineering, \\ Institut Teknologi Bandung, Indonesia, ofyar@trans.si.itb.ac.id \\ Idwan Santoso \\ Department of Civil Engineering, \\ Institut Teknologi Bandung, Indonesia, idwan2003@yahoo.com \\ Miming Miharja \\ School of Architecture, Planning and Policy Development, \\ Institut Teknologi Bandung, Indonesia, mimiharja@yahoo.co.id \\ doi:10.13165/ST-14-4-1-06
}

\begin{abstract}
Purpose. The widespread adoption of smartphones, which is the result of convergence of Information and Communication Technology, potentially influences work activities of mobile professionals: how they plan and execute their agenda, including working during their travels. This paper is aimed at gaining a first insight into understanding the behavioural changes in the activities and travel patterns of mobile professionals.

Design. Cross-sectional survey consists of 20 interviews and 50 questionnaires conducted to provide an initial overview of the transformations that occur in mobile


work in Indonesia as a developing country. Simulations using the stated adaptation approach were conducted to obtain basic response patterns that occur when information was received during the ongoing daily activities.

Findings. Smartphone adoption has provided mobile professionals with the ability to work in a novel way. They use smartphones as an information and communication tool throughout the day to improve productivity and to assure the efficiency of their "travelling" as part of their mobile work.

Research limitations. Ideally, to obtain the transformation rules of travel patterns, this study should be conducted with a larger sample size. This study uses only a limited number of samples, because it is only intended to provide an initial overview.

Practical implications. the basic pattern rule of the transformation is useful to give a better understanding of the phenomena.

Originality/Value. Indonesia is chosen as a case study to give an overview of the transformation that occurs as a result of the adoption of smartphones in the mobile work activities in developing countries.

Keywords: smartphone, mobile professional, travel pattern, activity.

Research type: research article.

\section{Introduction}

Information and Communication Technology (ICT) plays an increasingly important role in human life. Mokhtarian and Tal (2013) have argued that ICTs are absorbed in nearly all aspects of life because of three factors, i.e. (1) better availability of new technology as a result of technological improvement and cost reduction; (2) social changes and diffusion of innovations as they grow from early adopters to larger market followers; and (3) public policies that smooth the progress of ICT implementation. The number of mobile-cellular subscriptions worldwide will reach almost 7 billion by the end of 2014 (ITU, 2014).

New ICT developments have facilitated the transmission of large quantities of information at high speed and accuracy at relatively low costs. This even seems to have increased through the emergence of the smartphone, which is a contemporary kind of mobile phone that integrates a number of technologies for advanced computing ability and connectivity (Charlesworth, 2009) with built-in applications and internet access, digital voice services, text messages, e-mail, web browsing, camera, MP3 player and video viewing. Google/IPSOS (2011) reported that $89 \%$ of smartphone users used it throughout the day. Technological and social characteristics of this device make the users potentially change their behaviour; in particular on how, when and where people choose to use their time to conduct activities, more than the previous ICT devices have done.

Smartphone market itself started out in the business segment (Nielsen, 2012; RIM, 2013) and, especially, the so-called mobile professionals are the important beneficiaries here. Mobile professionals could be characterised as individuals over the 
age of 20, employed full time in professional occupation, who spend $20 \%$ or more of their total working time away from their work environment (Ablondi and Elliot, 1992). The nature of mobile professional work differs in many ways from desk work or fixed-node workers to mobile-node workers caused by contextual constraints (Kristoffersen and Ljungberg, 1999). For mobile professionals, work can be done not only in their formal office but also at various locations, such as in a house, at a client's office, hotel, cafe, and moving vehicles; they need additional information to support them. Thus, smartphones fulfil their needs. This is in line with Mokhtarian (2009) who has stated "the more one travels, the more useful, and used, a mobile phone becomes."

The issue of the interaction between the developments of ICT in individual travel behaviour is not a new thing. It is often expressed in terms of its function of substitution, complementarity, modification, and neutrality (Mokhtarian, 2009; Mokhtarian and Salomon, 2002; Niles, 1994; Salomon, 1986). On the substitution function, ICT replaces transports, where the use of ICT acts to reduce trip number, for instance by using tele-banking, tele-service, and online shopping. On the complementarity function, ICT generates or completes transports by improving access to information, where the use of ICT stimulates the trip number, for instance: a phone call, letter, e-mail message, or a fax prompting a trip or individual meetings over ICT devices prior to person-to-person meetings upon finding common interests and thus generating travels. On the modification function, ICT does not replace or evoke travels but change the time, mode or route of travels instead. And the last function, the neutrality function, the use of ICT and transport does not affect each other. In general, substitution, complementarity, modification and neutrality are happening simultaneously, but Mokhtarian (2009) reviews some studies and empirical facts and concludes that complementarity is the foremost impact. In order to investigate the impact of ICT, this study uses an activity based approach, which analyses and predicts travel behaviour resulting from incorporated activity decisions. This study particularly employs activity scheduling as an intermediary interaction between ICT and transports. Some researchers are also interested in researching how people perform their activity scheduling (e.g. Joh, 2004), but have not taken into account the effect of using a smartphone for such purpose. Therefore, there is still a gap that can be filled by this study. Research on mobile professionals in Indonesia is still very rare and is interesting to study, especially on how they work out of office and spend their time in urban transportation networks. Indonesia is selected as the case for this research due to the number of smartphone users in Indonesia that is continuing to rise up to $23 \%$ share (over 68 million users from overall 297 mobile phone subscribers) in 2013 (Suryo, 2014). Indonesia is expected to be a fast-growing smartphone market over the next few years (Mobithinking, 2014; Nielsen, 2012; Nugraha, 2012). Thus, it is alleged that urban transports in Indonesia will certainly deal with the consequences of the transformation behaviour due to the adoption of smartphones. In addition, Axhausen and Gärling (1992) argue that the re-scheduling of activities is an important part of many changes in the travel behaviour. Given the policy initiatives related to the information technology and transportation demand management, the understanding of the scheduling activities becomes increasingly important. 
The outline of the paper is as follows: the next section describes the theoretical background, which contains: smartphone technology, the nature of mobile work, and activity scheduling. Research methodology section presents the research design and expected outcomes, followed by the result of the survey and discussion, and the conclusion.

\section{Theoretical background}

\subsection{Technology of Smartphone and Mobile Interactions}

Recent Information and Communication Technology has the potential to transform everyday life: how to interact, privacy, social networking, economics, education, and urban transport (Miller, 2005). Most of the previous studies on mobile phones have tried to understand and explore mobile adoption and its potential changes in user behaviour due to the use of a mobile phone, from the perspective of sociology; for instance, Geser (2002) has focused on how mobile phone changes the way a person interacts socially. Kwan (2007) mentioned that mobile phone gave the possibility of new ways of doing activities. Based on time-geography proposed by Hägerstrand (1970), there are three types of space-time constraints which determine individual behaviour through time and across space; those are (1) capability constraints: human psychological limitations and instrumental limitations of material entities, including ICT devices; (2) coupling constraints: the need to spend some time in a certain place to conduct some activities (3) authority constraints: laws, rules and norms. Dijst (2009) has argued that the use of ICT has relieved some capability constraints and coupling constraint.

After the convergence of ICT, the motive for adopting smartphones is more powerful and it makes mobile phone users quickly shift to smartphones, which combine many of the applications of a computer with a cell phone. It is almost impossible to go out in public without seeing someone tapping away at a smartphone. Smartphones offer users the ability to check into social media sites, send and receive e-mail, perform transactions on bank accounts, pay bills, read books, instant message friends, watch television and movies, browse the internet, check the weather or location based service (LBS) source where locations of activities can be found and real time travel and route information can be gathered.

\subsection{The Raise of Mobile Professionals and Smartphone Usage during Work}

According to Hall (1968), a professional's characteristics revolve around the 'professional model' that consists of several structural and attitudinal criteria. Structural components for instance are formal education and entrance requirements of a job. Attitudinal components reflect the way employees view their job, e.g. the professional organisation as a major source of ideas and judgment for the professionals 
in their work, a belief that the work performed by them benefits the public, a belief in self-regulation, dedication to work, and autonomy (i.e. an ability to make one's own decisions without external pressures). Both the structural and attitudinal aspects are assumed to be present to a large extent in professionalised occupations.

Kakihara, et al. (2002) have argued that there is a tendency that the workforce has to deal with an increasingly complex job, with the expansion and globalisation of business activities rapidly increasing to cope with higher consumer demands. Technology developments and changing organisational demands lead to the rise of the 'post-modern' professionals who are mobile. They conduct their work activities at different locations rather than spend much time in the office. Moreover, post-modern professionals constantly interact with different people both inside and outside the formal organisation in a large geographical area. Kristoffersen and Ljungberg (1999) defined mobile work in three types: travelling, visiting and wandering. Travelling refers to "going from one place to another place". Visiting is an activity of "spending a long period at fixed point", while wandering involves extensive local mobility in a small area, for instance within an office building. Work-related travelling (or business trip (Aquilera, 2008) is an essential part of mobile work and a derived demand based on the needs to perform work activities, e.g. work to visit clients, participate in a conference or meeting with business relation.

\subsection{Activity Scheduling, Coordination and Activity (re)Scheduling}

During the recent decades, the decision-making process of activity scheduling has become an essential topic for transport researchers, including how people reschedule daily activities and travels in response to change. Clark (2001) has argued that rescheduling decisions include modifications/updates with time, location/route, the people involved, the event/mode types, and attributes of activities/trips, as well as deletions and additions of new events. The scheduling decisions come up as a part of an ongoing process over time, space and across individuals in order to revise and update their plans in an effort to resolve their daily activities and trips. Scheduling is the process of how people organise activities and movements, including the decision of what activities to do, where to do, modes and routes used, where, when, how long and with whom (Doherty et al., 2008). The area includes how a planned activity (preplanned) is implemented. The process of dynamic scheduling begins with premises of preplanning activities selected from the agenda, followed by re-planning and scheduling of continuous time, and ends with the pattern implementation of the activity-travel schedule. Townsend (2002) has emphasised that the need to coordinate the activities is the basic social function, especially in contemporary society, which is characterised by distributed residential locations, car-based transports, and complex activity patterns. They need to manage and co-ordinate daily schedules to harmonise everyday tasks and activities. Traxler (2010) has argued that another aspect of changes observed in the mobile work activities is the emergence of 'like jazz' effect to continue not only to align some of the activities but also to harmonise the activities planned with improvisation activities, and especially those done in the middle of doing the 
movement or during mobility. Apparently. what is meant by a mixture of planning and improvisation of activities is similar to "rescheduling of activities", which is revealed by Axhausen and Gärling (1992) and micro-coordination, which is meant by Ling (2004).

Based on literature review, we can say that the use of new ICT, specifically a smartphone, will potentially influence the travel behaviour of the users. The hypothesis of this paper is that smartphone adoption of mobile professionals makes activity scheduling more dynamic and influences their daily travel pattern".

\section{Study Design}

The research objective is to observe the subsequent changes and probabilities of adjustment caused by mobile interactions. This study explores the relationship between mobile interactions using smartphones, activity (re)scheduling, and daily travel patterns of mobile professionals by retrieving the experiences of the mobile professionals in using their smartphones.

A combination of semi-structured interviews and questionnaires was conducted in this stage with the aim of obtaining information on the context surrounding the mobile professionals' activities, for instance: why they made a trip, with whom they visited, what they would do with them, what they did with their mobile phone while travelling, and at a third location, how they used their phones, especially for work purposes, what has changed in their mobile work in the result of the implications of the use of smartphones, how they planned and made an activity-travel schedule, and how they executed the agenda (including how they reschedule the agenda). Also, travel diaries of respondents were recorded. Space-time path, which has been proposed by Hägerstrand (1970), is used to show the dynamics of activity scheduling, because an individual human activity takes place in a specific space-time context. All of the interviews were conducted in Indonesian, and the quotes have been translated into English. Interviews were transcribed and analysed for the identification and sorting of themes and core concepts. In this paper, the cited interview results are indicated using a three-letter code of the initial capital letters of the interviewees' names.

The conceptual frame of the study is shown in Figure 1. Figure 2 explains how the activity would be rescheduled and influence travel patterns.

Participants were also provided with a specific scenario to know the response if they faced a specific situation during the execution of the agenda. Ideally, we have to observe all of the detailed information received from the interactions using smartphones (e.g. forms, type of service, content, with whom, timing of interaction) and the attributes of the activity at that moment (e.g. people involved, fixity, temporal attribute, spatial attribute, characteristic of joint the activity). Considering that every mobile professional has a unique agenda and a broad spectrum, a stated adaptation was chosen. Stated adaptation study was applied because the direct observation of the real travels did not provide the necessary data to predict traffic and how people reacted to external changes (Bladel et al., 2008). In this study, the purpose of this 
approach is to simplify and compose the basic patterns of the activity changes due to the interactions using smartphones. The scenario should be made as real as possible, and in the most probable occurrences. The choice of options provided must also be made as close to reality as possible. Within this context, the storyboard was built based on the experiences expressed by the mobile professionals at preliminary interview. An example of the scenario is as follows: "In the morning, you are at the office, completing routine managerial matters, involving co-workers. Next event is a meeting with your customer (A), in the customer's office, which can take 30 minutes drive from the current location and suddenly you receive information on your smartphone. Your client suddenly calls and tells you about some serious problems in the field, with a distance of 2 hours drive and needs an immediate treatment. Your presence on the field is awaited. What might you do?" or "You get information through an application of traffic service on your smartphone about a traffic jam on the route to the next activity. What would you probably do?" The behavioural response to such a situation is recorded as "stated adaptation" and the basic pattern of activity as well as travel executed is then analysed.

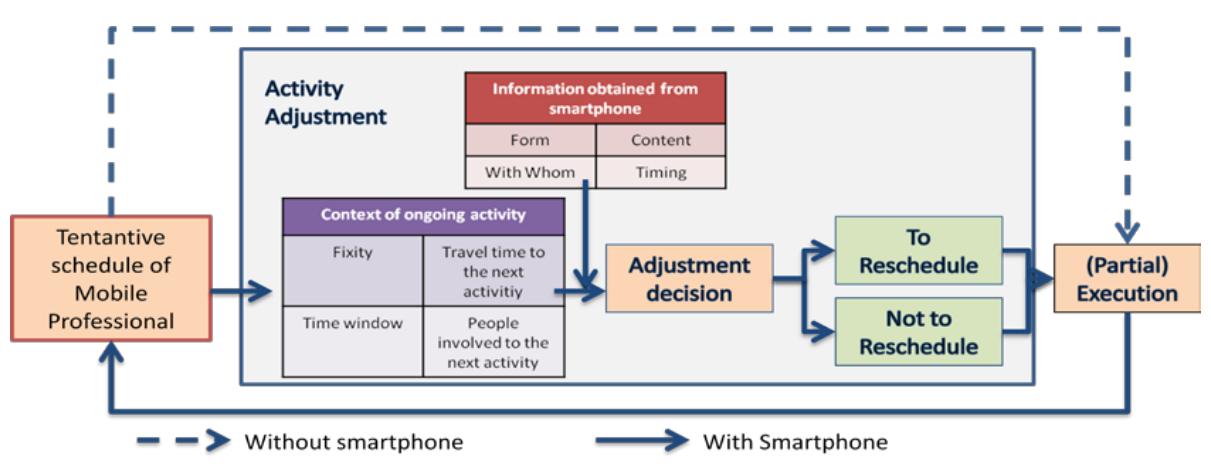

Figure 1. Conceptual frame

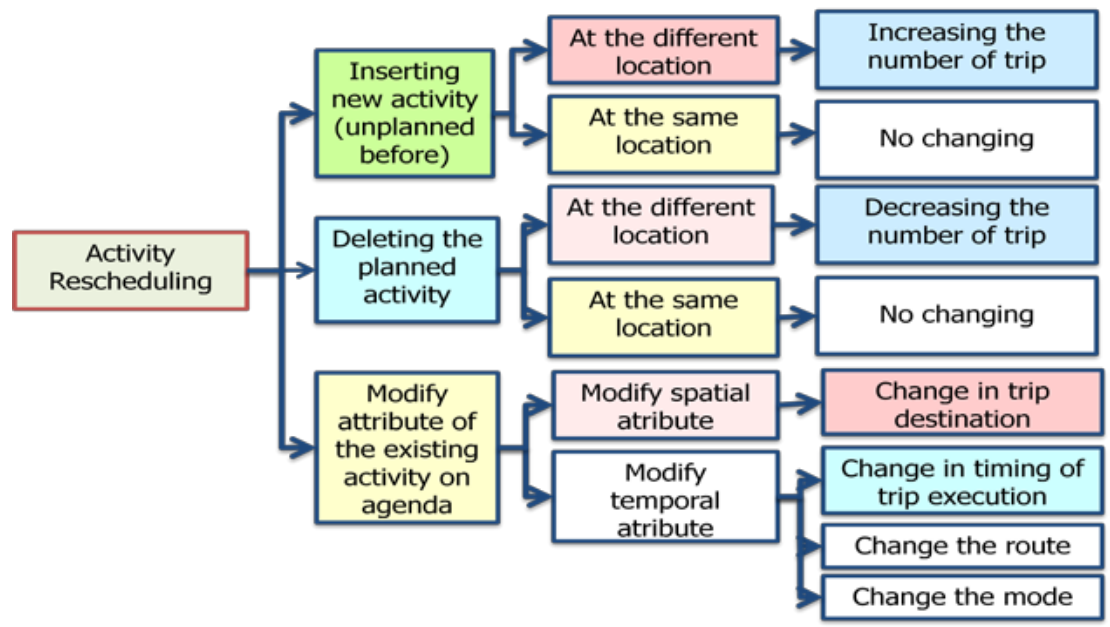

Figure 2. How activity rescheduling can influence a travel pattern 


\section{Results and findings}

\subsection{Profile of Respondent}

The survey was conducted with 70 respondents $(20$ semi-structured interviews and 50 questionnaires) from mobile professional-smartphone users in the Greater Jakarta area (Jakarta, Bogor, Depok, Tangerang, Bekasi), with a variety of professions (i.e. consultant, project management, journalist, lawyer, veterinarian, obstetricgynaecologist, contractor, marketing, sales, customer service specialist, managing partner, real estate developer, and government field-officer). The professional selection was based on a pre-screening in which respondents are actually the target of the research, i.e. more than $20 \%$ of the working time is spent out of office, as well as smartphone adopters. The profile of the respondents is given in Table 1.

Table 1. Profile of respondents

\begin{tabular}{|c|c|c|c|c|c|c|c|}
\hline Profile & $\%$ & Profile & $\%$ & Profile & $\%$ & Profile & $\%$ \\
\hline \multicolumn{2}{|l|}{ Gender } & Residence & & \multicolumn{2}{|l|}{ Level of Managerial } & \multicolumn{2}{|c|}{$\begin{array}{l}\text { Maximum location } \\
\text { to visit }\end{array}$} \\
\hline Male & $75 \%$ & Jakarta & $28 \%$ & Top & $33 \%$ & 2 places & $22 \%$ \\
\hline Female & $25 \%$ & Bogor & $13 \%$ & Middle & $67 \%$ & 3 places & $47 \%$ \\
\hline \multicolumn{2}{|l|}{ Age } & Depok & $17 \%$ & Expenditure/month & & $>3$ places & $31 \%$ \\
\hline $21-30$ & $6 \%$ & Tangerang & $8 \%$ & $<$ IDR 5 million & $3 \%$ & \multicolumn{2}{|c|}{ Smartphone Ownership } \\
\hline $31-40$ & $40 \%$ & Bekasi & $35 \%$ & IDR 5-20 million & $51 \%$ & $1-5$ years & $18 \%$ \\
\hline $41-50$ & $43 \%$ & \multicolumn{2}{|c|}{\begin{tabular}{|l|}
$\begin{array}{l}\text { Location of mobile } \\
\text { work }\end{array}$ \\
\end{tabular}} & >IDR 20 million & $46 \%$ & $>5$ years & $82 \%$ \\
\hline$>50$ & $11 \%$ & Jakarta & $100 \%$ & Mode to work & & \multicolumn{2}{|c|}{ Number of SIM card } \\
\hline \multicolumn{2}{|c|}{ Education } & Bogor & $60 \%$ & Motorcycle & $11 \%$ & Only 1 & $13 \%$ \\
\hline Bachelor & $57 \%$ & Depok & $22 \%$ & Car & $97 \%$ & $>1$ & $87 \%$ \\
\hline Master & $40 \%$ & Tangerang & $53 \%$ & $\begin{array}{l}\text { Public transport } \\
\text { (road) }\end{array}$ & $11 \%$ & \multicolumn{2}{|c|}{ Number of Smartphone } \\
\hline \multirow[t]{2}{*}{$P h D$} & $3 \%$ & Bekasi & $63 \%$ & Public transport (rail) & $8 \%$ & Only 1 & $13 \%$ \\
\hline & & & & & & $>1$ & $87 \%$ \\
\hline
\end{tabular}

\subsection{Nature of Mobile Work of Mobile Professionals}

In general, the activities carried out by mobile professionals outside their office consist mainly of planning meetings, attending meetings and making decisions at the meetings, servicing their clients, presenting their plans and explaining the progress of their work, and meeting with colleagues involved in the project at different locations.

The respondents are very dependent on their smartphones. They mostly have more than one smartphone and SIM card. They are early adopters of smartphone users and use it throughout the day and make use of the facilities and services offered 
(e.g. IM, voice call, e-mail, SMS, browsing), and take the benefit of them. Some reasons why they always turn on their phones throughout the day are: to enable coordination, to gain flexibility, to increase productivity, to improve efficiency, to feel convenient and safe, to avoid being labelled as an "irresponsible person", to prevent anxiety and being confused, and to prevent the frustration of the people who contact them.

\subsection{Implication of Using Smartphones on Individual Travel Patterns}

There is a change in the conditions of professional work as an implication of respondents who use mobile smartphones in order to meet the need for support information while being mobile. Because of the characteristic of being 'always connected' to smartphones, a mobile professional is more easily contacted and informed as well as sends real-time information. Interactions using smartphone allow them to make coordinations and harmonise the activities in everyday life. For mobile professionals, a smartphone is useful in providing access to resources and resulting in improved efficiency and connectivity with the company and their clients; hence they can be empowered and supported at a distance during their mobile work. They are still connected on 'after work hours' and even during holidays and still work although they are travelling or resting at home. They are also connected with their family and friends and tend to interact and respond to the information gathered from smartphone during the work.

During scheduling, smartphone is mostly used to make an appointment, to determine whether the meeting is important or not and to arrange a meeting. If the interaction is not extremely complicated, sometimes communications using a smartphone can replace a face-to-face meeting, as NKL (GM mining company, 40) said that his trip number has been decreasing since he has used a smartphone, because for activities that required exchange of information, the use of smartphones could replace the need to make a trip. Communications that do not involve copresence are more functional and task-oriented and less rich and multifaceted (Urry, 2004). DHD (account representative, 39) stated, “... usually if there is an immediate change, I use my smartphone to match the client's agenda and my activities. Activities and trips can be adjusted..." It shows that smartphone is a coordination tool that helps modify travel in the event of a change of activities and of arranging an adjustment. A respondent named EDP experienced a complementarity effect saying that "the total trip seems to increase. Because there is more information, there is more opportunity. If the opportunity is taken, it appears that the addition of new activities will increase the number of my daily trips." It can be understood that telecommunications can stimulate travels through a phone call, letter, e-mail message, and individual meetings over ICT devices prior to person-to-person meetings upon finding common interests. Generally, the increased ease of communication expands the size of our contact sets (Niles, 1994; Couclelis, 2009) and therefore increases the number of opportunities for face-to-face interactions. Moreover, Urry (2004) states that more virtual connections seem to bolster more extensive physical connections and hence more corporeal travel. 
On the basis of travel diary data from individual respondents, one case is presented here as an illustration of the experience of a respondent named HPS (property developer, age - 42), who had a tentative schedule as shown in Table 2. During the implementation, there were some interactions relevant to the activities of the day (Table 3). After making mobile interactions via his smartphone, he made adjustments twice (Table 4 and Table 5).

Table 2. Tentative Schedule of HPS (property developer, 42)

\begin{tabular}{|c|l|l|l|c|c|c|c|c|c|}
\hline No. & \multicolumn{1}{|c|}{ Origin } & Destination & Activity & $\begin{array}{c}\text { De- } \\
\text { par- } \\
\text { ture } \\
\text { Time }\end{array}$ & $\begin{array}{c}\text { Travel } \\
\text { Time }\end{array}$ & $\begin{array}{c}\text { Dis- } \\
\text { tance } \\
(\mathrm{km})\end{array}$ & $\begin{array}{c}\text { Start } \\
\text { time }\end{array}$ & $\begin{array}{c}\text { End } \\
\text { time }\end{array}$ & $\begin{array}{c}\text { Dura- } \\
\text { tion }\end{array}$ \\
\hline 1 & Sentul & Sentul City & office work & $8: 30$ & $0: 15$ & 7 & $8: 45$ & $9: 30$ & $0: 45$ \\
\hline 2 & Sentul City & Jungle Land & visiting project & $9: 30$ & $0: 20$ & 7,5 & $9: 50$ & $11: 30$ & $1: 40$ \\
\hline 3 & Jungle Land & Mosque & taking a pray & $11: 30$ & $0: 10$ & 7,0 & $11: 40$ & $12: 55$ & $1: 15$ \\
\hline 4 & Mosque & Sentul City & office work & $12: 40$ & $0: 15$ & 0,5 & $12: 55$ & $16: 00$ & $3: 05$ \\
\hline 5 & Sentul City & Sentul & Home & $16: 00$ & $0: 15$ & 7 & $16: 15$ & & \\
\hline & Time-home & $\mathbf{1 6 : 1 5 : 0 0}$ & & Total & $\mathbf{1 : 1 5}$ & $\mathbf{2 9}$ & & & $\mathbf{6 : 4 5}$ \\
\hline
\end{tabular}

Table 3. Smartphone usage and Impact on trip parameter of HPS

\begin{tabular}{|c|l|l|l|}
\hline Timing & Services & \multicolumn{1}{|c|}{ Content of Information related activity } & \multicolumn{1}{|c|}{$\begin{array}{c}\text { Impact to travel } \\
\text { characteristic }\end{array}$} \\
\hline $9: 00$ & IM, GM & $\begin{array}{l}\text { Pre-travel verification with staff and member } \\
\text { of project }\end{array}$ & On time-trip execution \\
\hline $16: 00$ & $\begin{array}{l}\text { SMS, } \\
\text { Voice }\end{array}$ & $\begin{array}{l}\text { Conversation with the client, arrangement of } \\
\text { a new appointment for 17:00 }\end{array}$ & $\begin{array}{l}\text { Travel time }+2 \text { hours, } \\
\text { travel length+60km }\end{array}$ \\
\hline $17: 30$ & Voice & $\begin{array}{l}\text { Contact the client, inform about the traffic } \\
\text { jam, delay the meeting to } 18: 00\end{array}$ & $\begin{array}{l}\text { Travel time }+3 \text { hours, } \\
\text { travel length }+60 \mathrm{~km}\end{array}$ \\
\hline
\end{tabular}

Table 4. Agenda Adaptation 1 ( $1^{\text {st }}$ rescheduling) of HPS

\begin{tabular}{|c|l|l|l|c|c|c|c|c|c|}
\hline No. & \multicolumn{1}{|c|}{ Origin } & Destination & Activity & $\begin{array}{c}\text { De- } \\
\text { par- } \\
\text { ture } \\
\text { Time }\end{array}$ & $\begin{array}{c}\text { Travel } \\
\text { Time }\end{array}$ & $\begin{array}{c}\text { Dis- } \\
\text { tance } \\
(\mathrm{km})\end{array}$ & $\begin{array}{c}\text { Start } \\
\text { time }\end{array}$ & $\begin{array}{c}\text { End } \\
\text { time }\end{array}$ & $\begin{array}{c}\text { Dura- } \\
\text { tion }\end{array}$ \\
\hline 1 & Sentul & Sentul City & office work & $8: 30$ & $0: 15$ & 7 & $8: 45$ & $9: 30$ & $0: 45$ \\
\hline 2 & Sentul City & Jungle Land & visiting project & $9: 30$ & $0: 20$ & 7,5 & $9: 50$ & $11: 30$ & $1: 40$ \\
\hline 3 & Jungle Land & Mosque & taking a pray & $11: 30$ & $0: 10$ & 7,0 & $11: 40$ & $12: 40$ & $1: 15$ \\
\hline 4 & Mosque & Sentul City & office work & $12: 40$ & $0: 15$ & 0,5 & $12: 55$ & $16: 00$ & $3: 05$ \\
\hline 5 & Sentul City & Cibubur & meeting-client & $16: 00$ & $1: 00$ & 30 & $17: 00$ & $18: 30$ & $1: 30$ \\
\hline 6 & Cibubur & Sentul & Home & $18: 30$ & $1: 00$ & 37 & $19: 30$ & & \\
\hline & Time-home & $\mathbf{1 9 : 3 0 : 0 0}$ & & Total & $\mathbf{3 : 0 0}$ & $\mathbf{8 9}$ & & & $\mathbf{8 : 1 5}$ \\
\hline
\end{tabular}


Table 5. Agenda Adaptation 2 (2 ${ }^{\text {nd }}$ rescheduling) of HPS

\begin{tabular}{|c|l|l|l|c|c|c|c|c|c|}
\hline No. & \multicolumn{1}{|c|}{ Origin } & Destination & \multicolumn{1}{|c|}{ Activity } & $\begin{array}{c}\text { De- } \\
\text { par- } \\
\text { ture } \\
\text { Time }\end{array}$ & $\begin{array}{c}\text { Travel } \\
\text { Time }\end{array}$ & $\begin{array}{c}\text { Dis- } \\
\text { tance } \\
(\mathrm{km})\end{array}$ & $\begin{array}{l}\text { Start } \\
\text { time }\end{array}$ & $\begin{array}{c}\text { End } \\
\text { time }\end{array}$ & $\begin{array}{c}\text { Dura- } \\
\text { tion }\end{array}$ \\
\hline 1 & Sentul & Sentul City & office work & $8: 30$ & $0: 15$ & 7 & $8: 45$ & $9: 30$ & $0: 45$ \\
\hline 2 & Sentul City & Jungle Land & visiting project & $9: 30$ & $0: 20$ & 7,5 & $9: 50$ & $11: 30$ & $1: 40$ \\
\hline 3 & Jungle Land & Mosque & taking a pray & $11: 30$ & $0: 10$ & 7,0 & $11: 40$ & $12: 40$ & $1: 15$ \\
\hline 4 & Mosque & Sentul City & office work & $12: 40$ & $0: 15$ & 0,5 & $12: 55$ & $16: 00$ & $3: 05$ \\
\hline 5 & Sentul City & Cibubur & meeting-client & $16: 00$ & $2: 00$ & 30 & $18: 00$ & $19: 30$ & $1: 30$ \\
\hline 6 & Cibubur & Sentul & Home & $19: 30$ & $1: 00$ & 37 & $20: 30$ & & \\
\hline & Time-home & $\mathbf{2 0 : 3 0 : 0 0}$ & & Total & $\mathbf{4 : 0 0}$ & $\mathbf{8 9}$ & & & $\mathbf{8 : 1 5}$ \\
\hline
\end{tabular}

Based on the experience of the respondent in performing mobile interactions through the use of a smartphone, space-time path of his tentative schedule and its implementation can be described as presented in Figure 3. It shows that, because of the mobile interaction using a smartphone, he rescheduled the activities by inserting new activities and consecutively the number of trips and travel distance has increased from 5 trips to 6 trips and from $29 \mathrm{~km}$ to $89 \mathrm{~km}$. Because of the adjustment he has made, his travel time has increased from 3 to 4 hours.

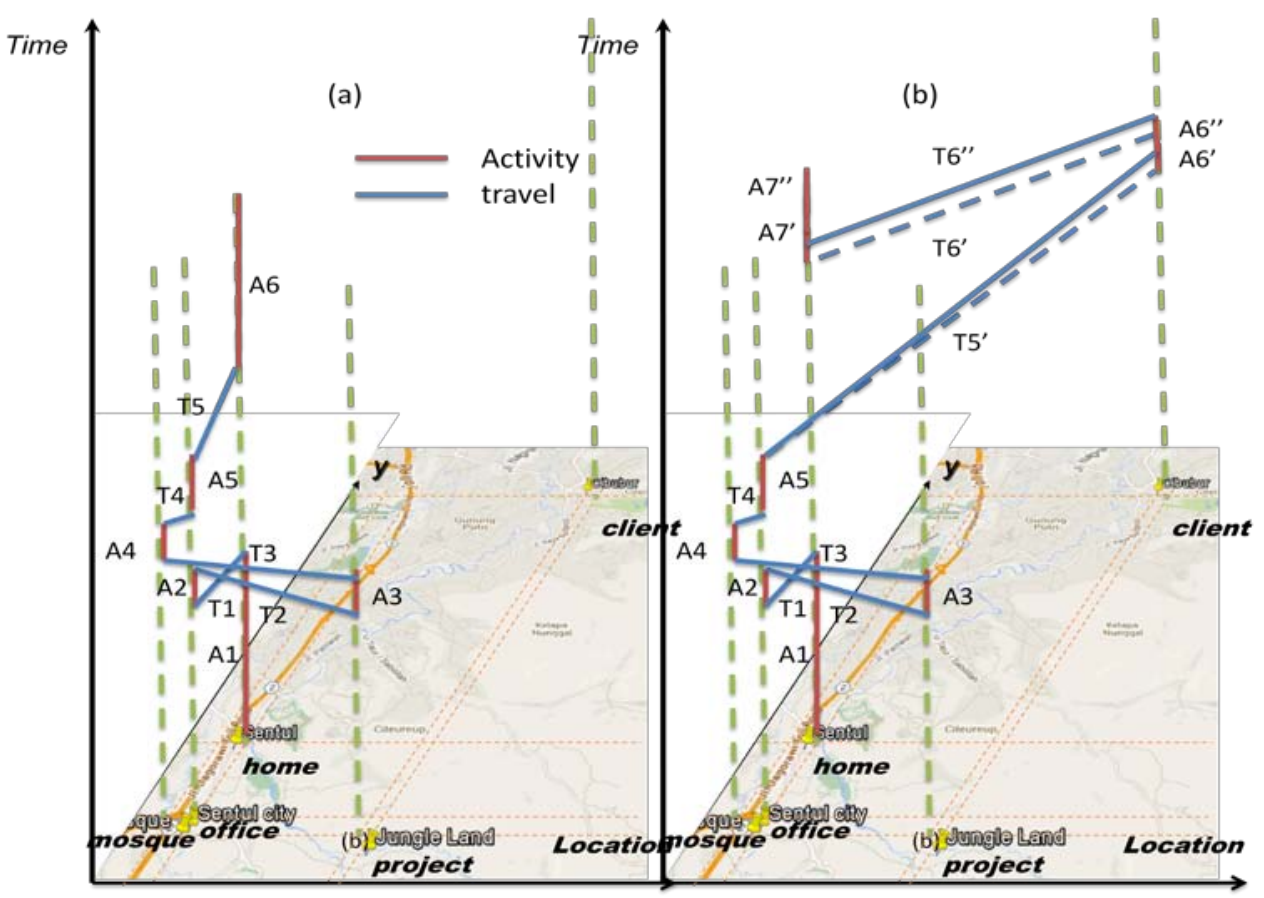

Figure 3. Space Time Path of HPS on the basis of activity-travel diary: tentative schedule (a) compare with execution (b) 
From the description above, after an individual schedule of activities and movements, options during activities emerge, including from the information received through smartphones. In this situation, after the information is received, the respondent sees the level of urgency, and then evaluates the information by looking at the agenda of the next event, considers the travel time, and then makes a decision whether to change the schedule or not.

\subsection{Overall Impact of Smartphone Adoption on Daily Activity Travel Execution}

On the basis of the travel diary experienced by respondents it was found that the travel characteristics of mobile professionals with smartphone usage (execution) and without smartphone usage (tentative schedule) was as shown in Table 6. It shows an increase in the number of average daily trips, travel distance and travel time. We can say that the empirical evidence for complementarity effect of smartphones is significant.

Table 6. Travel characteristics of mobile professionals, a comparison between tentative schedule and its execution

\begin{tabular}{|c|l|c|c|c|}
\hline No. & \multicolumn{1}{|c|}{ Travel Characteristic } & $\begin{array}{c}\text { Tentative } \\
\text { schedule }\end{array}$ & $\begin{array}{c}\text { Execution (with } \\
\text { smartphone usage) }\end{array}$ & $\begin{array}{c}\% \text { of } \\
\text { increase }\end{array}$ \\
\hline 1 & Daily travel distance (km) & 63,48 & 80,82 & $27 \%$ \\
\hline 2 & Average daily travel time (hour) & 3,17 & 4,04 & $27 \%$ \\
\hline 3 & Average number of trip (trip) & 4,47 & 5,13 & $15 \%$ \\
\hline
\end{tabular}

From the travel diary data, most of the respondents experienced the improvisation of their agenda during the implementation (inserting and modification; modification time or space; deleting and inserting; deleting and modifying time or space; no improvisation), as shown in Figure 4.

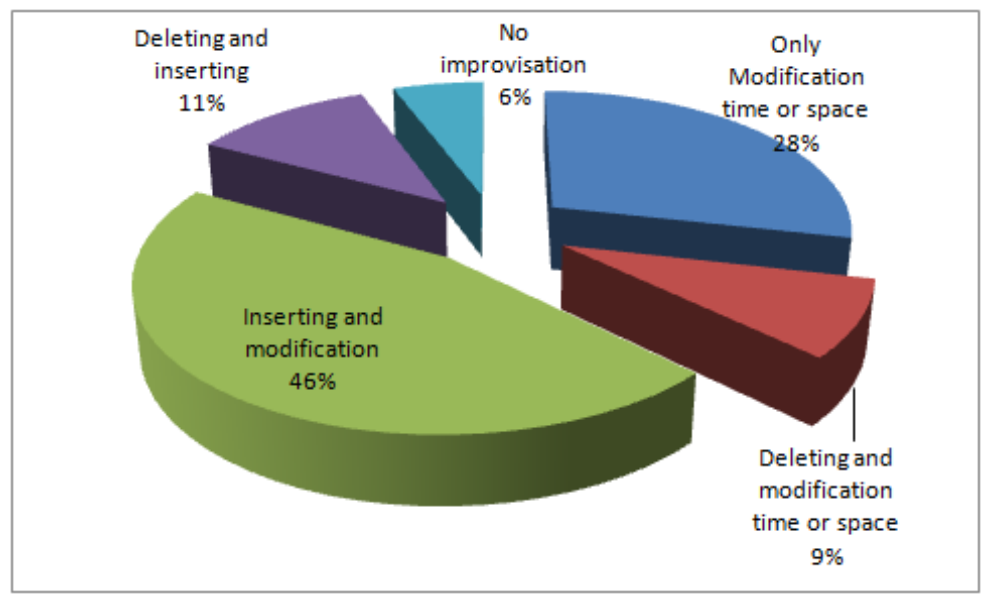

Figure 4. Experiences of re-scheduling the agenda of respondents 
The largest part of the improvisation experienced is "inserting and modification" (46\%) and only $6 \%$ of respondents experienced no improvisation. All of the respondents agreed that with smartphone adoption, they experienced higher dynamics of activity scheduling. It shows that mobile professionals always consider all the information gathered via smartphone that is relevant for the next agenda. Mobile professionals have to manage and balance the time spent for travels and activities, participate in activities planned and consider the real time information they have.

\subsection{General Rule of Adaptation Patterns}

Further, from the simulation using the stated adaptation approach, we obtained the basic rule based on a modus of response option. Bladel et al. (2008) have argued that the mechanisms that occur when a respondent chooses the option are (1) interpreting the data; (2) constructing the context cognitively; (3) applying the current preferences and strategies for building decision-making contexts; (4) mentally simulating the consequences of the available choices, judging the existing consequences and finally reporting the option. The result of simulation using 13 situation scenarios is showed in Table 7.

Behaviour against obtained information about the condition of the people involved in the subsequent activities and the environment plays an important role in determining the dynamic option. Individuals process information and decide to revise or continue the pattern that has been planned beforehand, and this influences the order, the attributes of space and time of the activities and, subsequently, the number of trips, timing, destination, length of trip, and travel time.

Table 7. Result of Simulation using 13 scenarios

\begin{tabular}{|c|l|l|l|l|}
\hline No. & \multicolumn{1}{|c|}{$\begin{array}{c}\text { Mobile } \\
\text { Interaction }\end{array}$} & \multicolumn{1}{|c|}{$\begin{array}{c}\text { Context of On Going and } \\
\text { Next Activity }\end{array}$} & \multicolumn{1}{|c|}{$\begin{array}{l}\text { Modus of } \\
\text { Respond }\end{array}$} & Impact on travel \\
\hline 1. & $\begin{array}{l}\text { Audio; with } \\
\text { Client; update; } \\
\text { morning }\end{array}$ & $\begin{array}{l}\text { Committed; time window: } 1-2 \\
\text { hours; } 1 \text { hour travel time, current: } \\
\text { with Colleague, next: with Client }\end{array}$ & $\begin{array}{l}\text { Modification of } \\
\text { time; delay of the } \\
\text { next activity }\end{array}$ & $\begin{array}{l}\text { Changing the } \\
\text { timing of trip } \\
\text { execution }\end{array}$ \\
\hline 2. & $\begin{array}{l}\text { Audio; with } \\
\text { family; } \\
\text { emergency; } \\
\text { morning }\end{array}$ & $\begin{array}{l}\text { Committed; time window: } 1-2 \\
\text { hours; } 30 \text { minutes travel time, } \\
\text { current: with Colleague, next: with } \\
\text { Client }\end{array}$ & $\begin{array}{l}\text { Deleting the } \\
\text { whole upcoming } \\
\text { activity }\end{array}$ & $\begin{array}{l}\text { Reduction of the } \\
\text { number of trips }\end{array}$ \\
\hline 3. & $\begin{array}{l}\text { Text; with web; } \\
\text { update; morning }\end{array}$ & $\begin{array}{l}\text { Committed, time window: } 1-2 \\
\text { hours, 30 minutes travel time; } \\
\text { current: with Colleague, next: with } \\
\text { Client }\end{array}$ & $\begin{array}{l}\text { Route modifica- } \\
\text { tion }\end{array}$ & $\begin{array}{l}\text { Route modifica- } \\
\text { tion }\end{array}$ \\
\hline 4. & $\begin{array}{l}\text { Audio; with } \\
\text { Client; update; } \\
\text { morning }\end{array}$ & $\begin{array}{l}\text { Committed; time window: 1-2 } \\
\text { hours, 30 minutes travel time; } \\
\text { current: with Colleague; next: with } \\
\text { Client }\end{array}$ & $\begin{array}{l}\text { Inserting without } \\
\text { deleting }\end{array}$ & $\begin{array}{l}\text { Increase the } \\
\text { number of trips }\end{array}$ \\
\hline
\end{tabular}




\begin{tabular}{|c|c|c|c|c|}
\hline 5. & $\begin{array}{l}\text { Audio; with } \\
\text { Friend; new ap- } \\
\text { pointment; before } \\
\text { lunch }\end{array}$ & $\begin{array}{l}\text { Optional; time window: } 1-2 \text { hours; } \\
30 \text { minutes travel time; current: } \\
\text { with client, next: none/tentative }\end{array}$ & $\begin{array}{l}\text { Modification of } \\
\text { activity space, } \\
\text { closer to the next } \\
\text { activity }\end{array}$ & $\begin{array}{l}\text { Changing the } \\
\text { trip destination, } \\
\text { reduction of trav- } \\
\text { elling distance }\end{array}$ \\
\hline 6. & $\begin{array}{l}\text { Audio; with } \\
\text { Client; new ap- } \\
\text { pointment; before } \\
\text { lunch }\end{array}$ & $\begin{array}{l}\text { Optional; time window: } 1-2 \text { hours; } \\
30 \text { minutes travel time; current: } \\
\text { with client, next: none/tentative }\end{array}$ & $\begin{array}{l}\text { Modification of } \\
\text { activity space, } \\
\text { closer to the next } \\
\text { activity }\end{array}$ & $\begin{array}{l}\text { Changing the } \\
\text { trip destination, } \\
\text { decreasing travel } \\
\text { length }\end{array}$ \\
\hline 7 & $\begin{array}{l}\text { Audio; with } \\
\text { Client; New Ap- } \\
\text { pointment; Lunch } \\
\text { time }\end{array}$ & $\begin{array}{l}\text { Committed; time window: } 1-2 \\
\text { hours; } 1 \text { hour travel time; current: } \\
\text { with client; next : with client }\end{array}$ & $\begin{array}{l}\text { Deleting the } \\
\text { next activity and } \\
\text { inserting new } \\
\text { activity }\end{array}$ & $\begin{array}{l}\text { Decreasing travel } \\
\text { length }\end{array}$ \\
\hline 8. & $\begin{array}{l}\text { Text; with Client; } \\
\text { New Appoint- } \\
\text { ment; Lunch time }\end{array}$ & $\begin{array}{l}\text { Committed; time window: 1-2 } \\
\text { hours; } 1 \text { hour travel time; current: } \\
\text { with client; next: with client }\end{array}$ & $\begin{array}{l}\text { Inserting a new } \\
\text { activity }\end{array}$ & $\begin{array}{l}\text { Increasing the } \\
\text { number of trip }\end{array}$ \\
\hline 9. & $\begin{array}{l}\text { Audio; with } \\
\text { Client; update; } \\
\text { Lunch time }\end{array}$ & $\begin{array}{l}\text { Committed; time window: } 1-2 \\
\text { hours; } 1 \text { hour travel time; current: } \\
\text { with client, next: with client }\end{array}$ & $\begin{array}{l}\text { Delay the next } \\
\text { activity }\end{array}$ & $\begin{array}{l}\text { Modification of } \\
\text { Execution Time } \\
\text { of departure }\end{array}$ \\
\hline 10. & $\begin{array}{l}\text { Text; with family; } \\
\text { emergency; After } \\
\text { mid day }\end{array}$ & $\begin{array}{l}\text { Optional; time window: } 1-2 \text { hours } \\
\text {; } 1 \text { hour travel time; current: with } \\
\text { client, next: with friend }\end{array}$ & $\begin{array}{l}\text { Deleting the next } \\
\text { activity }\end{array}$ & $\begin{array}{l}\text { Reducing the } \\
\text { number of trip }\end{array}$ \\
\hline 11. & $\begin{array}{l}\text { Text, with friend, } \\
\text { update, After mid } \\
\text { day }\end{array}$ & $\begin{array}{l}\text { Optional; time window: } 1-2 \text { hours; } \\
1 \text { hour travel time; current: with } \\
\text { client; next: with friend }\end{array}$ & $\begin{array}{l}\text { Deleting the next } \\
\text { activity }\end{array}$ & $\begin{array}{l}\text { Reducing the } \\
\text { number of trip }\end{array}$ \\
\hline 12. & $\begin{array}{l}\text { Text, with family, } \\
\text { update, After mid } \\
\text { day }\end{array}$ & $\begin{array}{l}\text { Optional; time window: } 1-2 \\
\text { hours; } 1 \text { hour travel time; current: } \\
\text { with client; next: with friend }\end{array}$ & $\begin{array}{l}\text { Inserting a new } \\
\text { activity }\end{array}$ & $\begin{array}{l}\text { Increasing trip } \\
\text { number and } \\
\text { modification of } \\
\text { departure time of } \\
\text { the next activity }\end{array}$ \\
\hline 13. & $\begin{array}{l}\text { Text; with Group; } \\
\text { update; After Mid } \\
\text { day }\end{array}$ & $\begin{array}{l}\text { Optional; time window: } 1-2 \text { hours; } \\
2 \text { hour travel time; current: with } \\
\text { client, next: with friend }\end{array}$ & $\begin{array}{l}\text { Deleting the next } \\
\text { activity }\end{array}$ & $\begin{array}{l}\text { Reducing the } \\
\text { number of trip }\end{array}$ \\
\hline
\end{tabular}

Based on the respondent's characteristics, gender, age, and managerial levels of the respondents play an important role in determining the option. For instance, in scenarios 2, 10 and 12 (family-related information), female respondents have strong modus in their response options. Valcour and Hunter (2004) have stated that women are more family-oriented and are more likely to intersperse their paid work with family related activities than men. When compared to men, women are more reactive and immediately make adjustments to their daily activities as soon as they get important information about their families.

This qualitative approach provides a preliminary observation of the potential changes in user travel behaviour. Simulations with a larger sample size can also be considered as a tool to examine behavioural rules in various combinations of situation. 


\section{Conclusion}

Empirical evidence with respect to the impact of smartphone adoption on the activity-travel pattern shows that the complementarity effect of ICT on the travel is significant. The travel characteristics of mobile professionals who are smartphone users indicate increases in the number of trips, total trip length and their travel time. Mobile professional always turn on their smartphones throughout the day and make them always connected. They use smartphones as an information and communication tool to organise their work at different locations, to improve their productivity, to conduct mobile-based coordination and to assure the efficiency of their "travelling".

Generally, mobile professionals who use smartphones experience a more dynamic daily activity-travel pattern, which is indicated by the improvisation of the tentative schedule they have made. They make adjustments during the execution of their schedule as they receive real time information via the smartphone.

This paper is a part of on-going research and will continue to evolve to the next research steps. To investigate the changes that occur in the presence of coordination using mobile smartphones based on the overall daily activities will be difficult because of their variability. Therefore, we need a more feasible approach, for example by looking at the changes that occur in two successive events using the stated adaptation. This can be a first step toward understanding the basic pattern of changes in one's travel activities with the use of smartphones. The use of this method with a larger sample size shall be investigated in further research, to gain a better result of capturing the dynamics of mobile professionals' activity-travel patterns influenced by the adoption of smartphones.

\section{References}

Ablondi, W.; Elliot, T. 1992. Mobile Professional Market Segmentation Study. BIS

Aquilera, A. 2008. Business Travel and Mobile Workers. Transportation Research. Part A, General 42, 8, pp. 1109-1116

Axhausen, K.; Gärling, T. 1992. Activity-Based Approaches to Travel Analysis: Conceptual Frameworks, Models, and Research Problems. Transport Review 12, 324-341.

Bladel, K. V.; Bellemans, T.; Janssens D.; Wets, G.; Arentze, T.; Timmermans, H.J.P. 2008. Design of Stated Adaptation Experiment: Discussion of Some Issues and Experiences. Proceeding at the $8^{\text {th }}$ International Conference on Survey Methods in Transport (ISCTSC), Annecy, France.
Charlesworth, A. 2009. The Ascent of Smartphone. Engineering and Technology Magazine, 4(3): 32.

Clark, A. 2008. The Human Activity-Travel Rescheduling Decision Process, Thesis of Master of Arts/Master of Environmental Studies degree Wilfrid Laurier University.

Couclelis, H. 2009. Rethinking Time Geography in the Information Age. Environment and Planning, 41: 1556-1575.

Doherty, S. T., Clark, F. A. 2008. Examining the Nature and Extent of the ActivityTravel Preplanning Decision Process. Transportation Research Record: Journal of the Transportation Research Board, No. 2054. 
Geser, H. 2004. Towards a Sociological Theory of the Mobile Phone. In: Sociology in Switzerland: Sociology of the Mobile Phone. Online Publications, Zuerich, March 2004 (Release 3.0). <http://socio.ch/mobile/t_ geser1.htm>

Google/IPSOS OTX Media CT. 2011. The Mobile Movement, Understanding Smartphone Users, U.S. [interactive]. <http://www.thinkwithgoogle.com/ research-studies/the-mobile-movement. html>.

Hägerstrand, T. 1970. What about people in Regional Science? Regional Science, 24(1).

Hall, R. H. 1968. Professionalization and bureaucratization. American Sociological Review, 33(1): 92-104.

ITU Telecom World. 2014. The World in 2014. ICT Fact and Figure, ICT Data and Statistics Division Telecommunication Development Bureau International Telecommunication Union. Switzerland.

Joh, C.H. 2004. Measuring And Predicting Adaptation In Multidimensional ActivityTravel Patterns, PhD Dissertation Faculteit Bouwkunde, Capaciteitsgroep Stedebouw, Technische Universiteit Eindhoven.

Kakihara, M., C.; Sorensen, M.; Wiberg. 2002. Fluid interaction in mobile work practices. Proceeding of 1st Tokyo Mobile Roundtable, Mobile Innovation Research Program, Insitute of Innovation Research Hitotsubashi, Tokyo Japan

Kristoffersen, S.; Ljungberg, F. 1999. Making Place to Make IT Work: Empirical Explorations of HCI for Mobile CSCW. GROUP'99: Proceedings of the international ACM SIGGROUP conference on supporting group work. ACM Press

Kwan, M. P. 2007. Mobile Communications, Social Networks, and Urban Travel: Hypertext as a New Metaphor for Conceptualizing Spatial Interaction. The Professional Geographer. 59:4, Routlegde, 2007.

Ling, R. 2004. The mobile connection (The cell phone's impact on society), Morgan Kaufman publishers.
Miller, H.J. 2005. What about people in geographic information science?. RePresenting Geographical Information Systems. P. Fisher and D. Unwin. (editors), John Wiley

Mokhtarian P.L.; Salomon, I. 2002. Emerging travel patterns: Do telecommunications make a difference? In Perpetual Motion: Travel Behavior Research Opportunities And Application Challenges, edited by H. S. Mahmassani. Oxford, UK: Pergamon Press/ Elsevier

Mokhtarian, P. 2009. If Telecommunication is such a good substitute for travel, why does congestion continue to get worse? Transportation Letters: The International Journal of Transportation Research: (1-17)

Mokhtarian, P.; Tal, G. 2013. Impacts of ICT on Travel Behavior: A Tapestry of Relationships. J. Rodrigue, T. Notteboom, \& J. Shaw (Eds.), The SAGE handbook of transport studies. (p. 241-261). 55 City Road, London: SAGE Publications, Ltd

Nielsen. 2012. Smartphone Ownership On The Rise In Asia Pacific, Whilst Advertisers Struggle To Engage With Consumers Via Mobile Ads. Nielsen

Niles, J. S. 1994. Beyond Telecommuting: A New Paradigm for the Effect of Telecommunications on Travel. Report number DOE/ER-0626, prepared for the US Department of Energy Office of Energy Research and Office of Scientific Computing, Washington, DC, September.

Nugraha, F. 2012. Total number of Mobile phone subscriber almost reach the total number of Population in Indonesia. Teknojurnal 18 January 2012, www. teknojurnal.com. In Indonesian. [accessed on 2012-11-23]

RIM. 2003. Blackberry Target Market. Overview. Research in Motion Limited. U.S. Salomon, I. 1986. Telecommunications and travel relationships: A review. Transportation Research A 20A(3): 223-238 Suryo, Y. 2014. Fact on Smartphone Users in Indonesia. The Canopy Asia. 
Townsend, A. 2002. Life in the Real Time City: Mobile Telephones and the Urban Metabolism. Journal of Urban Technology, 7(2), 85-104.

Traxler, J. 2010. The Learner Experience of Mobiles, Mobility and Connectedness. ELESIG, [accessed on 2012-11-22]. <http:// www.ingedewaard.net/ papers/mobile/2011_JohnTraxler_The LearnerExperienceOfMobilesMobility_ Connectedness.pdf>
Urry, J. 2004. Connections. Environment and Planning D: Society and Space, 22: 27-37. Valcour, P. M.; Hunter, L. W. 2005. Technology, organizations, and work-life integration. Managing work-life integration in organizations: Future directions for research and practice. E. E. Kossek, S. J. Lambert, Mahwah, NJ: Erlbaum: 61-84. 